\title{
IL-6 gene rs1800795 polymorphism and diabetes mellitus: a comprehensive analysis involving 39099 participants
}

\section{CURRENT STATUS: POSTED}

Research Square

\section{Zhang Chunmin}

xinqiao town community health service center

zhangchunmingsh@126.comCorresponding Author

ORCiD: https://orcid.org/0000-0002-7211-2568

\section{Zhiying Cheng}

xinqiao town community health service center

\section{DOI:}

10.21203/rs.2.16985/v1

\section{SUBJECT AREAS}

\section{Medical Genetics}

\section{KEYWORDS}

Interleukin-6, Type 2 Diabetes Mellitus, Type 1 Diabetes Mellitus, polymorphism, risk, meta-analysis 
Abstract

Background Over the past two decades, many studies concentrated the association between a common polymorphism ( rs1800795 ) from interleukin-6 (IL-6) gene and Diabetes Mellitus (DM) risk have been published, however, the results remain ambiguous and indefinite. Methods In current, we performed a comprehensive analysis to explore above relationship. A search was conducted in the PubMed, Embase, Chinese (CNKI and Wanfang) databases, covering all papers published until Sep 20, 2019. Odds ratios (OR) with $95 \%$ confidence intervals $(\mathrm{Cl})$ was applied to evaluate the strength of this association. Publication bias was assessed with both Begg and Egger's tests. Results Overall, 26 casecontrol studies with 5973 T2DM patients and 13968 controls, and 11 case-control studies (10193 T1DM patients and 8965 health controls) were included for analysis in our study. Finally, significant decreased association was observed between the rs1800795 polymorphism and T2DM risk in overall sample, Asians and hospital-based subgroup (for example: C-allele vs. G-allele: $\mathrm{OR}=0.65,95 \% \mathrm{Cl}=$ 0.53-0.81, $\mathrm{P}<0.05)$, however, increased associations were found from Mixed population and hospitalbased subgroup between rs1800795 polymorphism and T1DM susceptibility (for example: CC vs. GG: $\mathrm{OR}=2.45,95 \% \mathrm{Cl}=1.18-5.07, \mathrm{P}=0.016$ for Mixed individuals).Conclusions In summary, there had a definite evidence to confirm that IL-6 rs1800795 polymorphism was associated with susceptibility of decreased T2DM and increased T1DM.

\section{Background}

Diabetes Mellitus (DM) is a chronic medical condition in which the body either produces too little insulin from pancreatic islet or has a lack of effective access to insulin [1]. Type 1 DM (T1DM) is most often diagnosed in children and adolescents about the development of islet function. Type 2 DM (T2DM) is due to insulin resistance, that the body can't use insulin effectively and may gradually mislay the production capacity [2-4]. To our current knowledge, age, obesity and a family history are risk factors for developing of DM [5]. However, the exact pathogenesis of DM is still not fully understood. Past genome-wide association studies (GWAS) already identified over 100 genetic sites, which supported that there have significantly associations between different sites and susceptibility of DM, it also means genetic factors may be crucial for its occurrence and development $[6,7]$. 
Interleukin-6 (IL-6), as a classic proinflammatory cytokine, plays a prominent role in inflammatory response, which is associated with insulin-resistant states and T2DM [8]. In addition, chronic lowgrade inflammation and activation of the innate immune system are closely involved in the pathogenesis of TIDM and its complications. Inflammatory cytokines, such as IL-6, are shown to be determinant in these pathogenic processes $[9,10]$.

The IL-6 gene is located at chromosome 7p21. The gene including seven exons covers approximately 12.8 kb of genomic DNA [11]. A common single nucleotide polymorphism (SNP) in the IL-6 promoter was first discovered and identified, named rs1800795 (also named -174G/C) in T2DM [12]. The rs1800795 polymorphism has been suggested to functionally affect IL-6 promoter activity, which showed the carried CC genotype individual is associated with lower plasma levels of IL-6 compared with individuals with GG genotype [13], in addition, whose G-allele in homozygous (GG genotype) was associated with higher concentrations of IL-6 increasing the immune response [14, 15].

Several epidemiological studies have supported the associations between genetic variants of IL- 6 and risk of DM. For instance, Saxena et al. suggested rs1800795 polymorphism showed a highly significant association with T2DM [16]. On the contrary, Dhamodharan et al. determined C-allele conferred significant protection against T2DM [17]. Besides, Fathy et al. [18] demonstrated that the lack of significant association between rs1800795 polymorphism and T2DM was detected. For T1DM, increased association was found between T1DM and this polymorphism from Cooper et al. [19], however, Tsiavou et al. observed no significant differences were existed [20]. Two meta-analyses (Yin and $\mathrm{Xu}$ et al.) both showed that rs1800795 was not associated with T1DM risk [21, 22]. Although, Huth and Xia et al. both made meta-analysis and had a conclusion that this polymorphism could be associated with the decreased risk of $\operatorname{T2DM}[23,24]$, little aspects had significant results. In the last ten years, some larger and comprehensive research on the association has been carried out and published. For the controversial conclusions between rs1800795 polymorphism and T1DM/T2DM, it is necessary to perform an updated meta-analysis to clarify the association [12, 15-20, 25-52].

Methods

\section{Document retrieval and data extraction}


We made use of searches on databases, including Pubmed, Embase, CNKI and Wanfang, until on Sep 20, 2019, with keywords including 'Interleukin-6/IL-6', 'polymorphism/variant' and 'Diabetes Mellitus/DM/TIDM/T2DM'. Eligible studies must be according with the following criteria: @) the studies assess the association between TIDM or T2DM and rs1800795 variants; @) case/control studies; @) age-and gender-matched control subjects. The criteria for exclusion were @) not case/control studies; @) insufficient genotype frequency; @) duplicated studies and @) significantly biased articles. The information including name of first author, year of publication, origin, race, DM type, genotype methods, Hardy-Weinberg equilibrium (HWE) were collected.

\section{Statistic analysis}

The correlation between IL-6 rs1800795 polymorphism and the risk of TIDM/T2DM was measured by $95 \% \mathrm{Cl}$ and $\mathrm{OR}$ according to the genotype frequencies of cases and control groups. Ethnic group are divided into African, Mixed, Caucasian and Asian. Population-based (PB) and hospital-based (HB) control subgroups were collected.

The statistical significance of the summary is calculated by Z-test. In these studies, the heterogeneity hypothesis was assessed by Q-test based on chi-square [53]. If significant heterogeneity $(<0.1)$ is detected, the random model is carried out, otherwise the fixed effect model is selected [54, 55]. For IL-6 rs1800795, we studied the relationship between variation and the risk of T2DM in C-allele vs. Gallele, CG vs. GG and CC+CG vs. GG models; and C-allele vs. G-allele, CC vs. GG, CC vs. CG+GG, CG vs. GG and CC+CG vs. GG models for TIDM risk. The asymmetry of funnel plot was evaluated by Begg's test, and the publication bias was evaluated by Egger's test, whose $P$-value $<0.05$ was considered significant [56]. Pearson chi-square test was used in the control group $(P<0.05)$, and $\chi^{2}$ test was used to evaluate the deviation of rs1800795 polymorphism from the expected frequency of HWE [57]. All above statistical tests were conducted using Stata (Version 11.0; Statacorp LP, College Station of Texas). The power of our meta-analysis was calculated online using the website http://www.power-analysis.com/. 
Results

\section{Study selection and characteristics}

A total of 1134 articles were identified from main four databases (Pubmed, Embase, CNKI and Wanfang) based on above search criteria. Among them, 35 articles were excluded because of following reasons: systematic analysis/meta-analysis (8), just only case study (6), other polymorphisms in IL-6 gene (12), not sufficient data of each genotype (5) and duplication (4) (Figure 1). Thus, a total of 40 different articles [13-18] accounting for a total of 16581 DM patients and 23799 healthy controls were included in our meta-analysis (29 case-control studies including 6388 T2DM patients and 10193 controls, and 11 case-control studies including 14834 T1DM and 8965 controls, respectively) (Table 1). Additionally, we tried to compare the minor allele frequency (MAF) between our current study and data from 1000Genomes (https://www.ncbi.nlm.nih.gov/snp/rs1800795\#frequency_tab). Five types of ethnicity are listed from 1000Genomes: African:0.018, East Asian: 0.001, Europe: 0.416, South Asian:0.14, American:0.18 (Figure 2). The MAF of T2DM subjects and controls was 0.331 and 0.387 , respectively; of T1DM patients and controls was 0.331 and 0.43 , respectively. The distribution of genotypes in controls was not consistent with the HWE in T2DM (9 case-controls) and T1DM (2 case-controls), respectively (Table 1). Genotyping of the SNPs of IL-6 gene rs1800795 polymorphism was conducted using some different genotype methods in Table 1.

\section{IL-6 rs1800795 polymorphism and T2DM risk.}

The results of the overall meta-analysis suggested negative associations between this polymorphism and T2DM susceptibility in two genetic models $\left(\mathrm{OR}_{\mathrm{C} \text {-allele vs. G-allele }}=0.85,95 \% \mathrm{Cl}=0.75-0.96\right.$,

$P_{\text {heterogeneity }}<0.001, P=0.008 ; \mathrm{OR}_{\mathrm{CC}+\mathrm{CG} \text { vs. GG }}=0.84,95 \% \mathrm{Cl}=0.70-0.99, P_{\text {heterogeneity }}<0.001, P$ $=0.039$ ) (Table 2, Figure 3a). If these studies not consistent with HWE were excluded, no significant result were detected in all three models. Analysis of ethnicity subgroups showed statistically significant association in Asians $\left(\mathrm{OR}_{\mathrm{C} \text {-allele vs. } \mathrm{G} \text {-allele }}=0.65,95 \% \mathrm{Cl}=0.53-0.81\right.$, $P_{\text {heterogeneity }}=0.060, P<0.001 ; \mathrm{OR}_{\mathrm{CC}+\mathrm{CG} \text { vs. GG }}=0.72,95 \% \mathrm{Cl}=0.51-1.00, P_{\text {heterogeneity }}=0.006, P$ 
$=0.053$, Figure $\mathbf{3 b}$ ). To our surprise, a marginally and poorly significant difference was found in the

$\mathrm{HB}$ sources of control subgroup $\left(\mathrm{OR}_{\mathrm{C} \text {-allele vs. G-allele }}=0.82,95 \% \mathrm{Cl}=0.69-0.97, P_{\text {heterogeneity }}<0.001\right.$, $P<0.022$, Figure 4) (Table 2).

\section{IL-6 rs1800795 polymorphism and T1DM risk.}

There was no significantly positive association between rs1800795 polymorphism and TIDM susceptibility in both total and subgroup consistent with HWE (for example: $\mathrm{R}_{\mathrm{C} \text {-allele vs. G-allele }}=1.16$, $95 \% \mathrm{Cl}=0.94-1.42, P_{\text {heterogeneity }}<0.001, P=0.162, \mathrm{OR}_{\mathrm{CC}}$ vs. GG $=1.38,95 \% \mathrm{Cl}=0.87-2.17$, $P_{\text {heterogeneity }}<0.001, P=0.169$; studies consistent with $\mathrm{HWE}: \mathrm{OR}_{\mathrm{CG}}$ vs. GG $=1.19,95 \% \mathrm{Cl}=0.89$ $1.58, P_{\text {heterogeneity }}=0.003, P=0.235, \mathrm{OR}_{\mathrm{CC}+\mathrm{CG} \text { vs. GG }}=1.18,95 \% \mathrm{Cl}=0.86-1.62, P_{\text {heterogeneity }}<$ $0.001, P=0.306$ ) (Table 3). The important finding was that there had a risk association between this polymorphism in Mixed population $\left(\mathrm{OR}_{\mathrm{C} \text {-allele vs. G-allele }}=1.39,95 \% \mathrm{Cl}=1.10-1.77, P_{\text {heterogeneity }}=\right.$ $0.497, P=0.006, \mathrm{OR}_{\mathrm{CC}}$ vs. GG $=2.45,95 \% \mathrm{Cl}=1.18-5.07, P_{\text {heterogeneity }}=0.486, P=0.016, \mathrm{OR} \mathrm{CC}+\mathrm{CG}$ vs. $\mathrm{GG}=1.43,95 \% \mathrm{Cl}=1.07-1.90, P_{\text {heterogeneity }}=0.724, P=0.015, \mathrm{OR}_{\mathrm{CC}}$ vs. $\mathrm{CG}+\mathrm{GG}=2.20,95 \% \mathrm{Cl}=$ 1.08-4.48, $P_{\text {heterogeneity }}=0.487, P=0.031$, Figure 5a,b,c,d). Similar relationships were observed for sources of $\mathrm{HB}$ subgroup (for example: $\mathrm{OR}_{\mathrm{C} \text {-allele vs. G-allele }}=1.29,95 \% \mathrm{Cl}=1.07-1.56, P_{\text {heterogeneity }}$ $=0.122, P=0.009, \mathrm{OR}_{\mathrm{CG} \text { vs. } \mathrm{GG}}=1.47,95 \% \mathrm{Cl}=1.11-1.94, P_{\text {heterogeneity }}=0.428, P=0.008$, Figure 6a,b,c,d) (Table 3).

\section{Publication bias and sensitive analysis}

Begg's and Egger's test were performed to assess publication bias, which was not found both for T2DM and T1DM analysis (for example: T2DM: $t_{C \text {-allele vs. G-allele }}=-1.66, P=0.108$ for Egger's test, $z=$ $0.77, P=0.441$ for Begg's test, Figure 7a,b; T1DM: $t_{\mathrm{C} \text {-allele vs. G-allele }}=1.64, P=0.136$ for Egger's test, $z=1.25, P=0.213$ for Begg's test, Figure $\mathbf{8 a}, \mathbf{b}, \mathbf{T a b l e ~} \mathbf{4})$. To delete studies which may influence the power and stability of whole study, we applied the sensitive analysis, finally, also no 
sensitive case-control studies were found (Figure 9,10, Table 4).

Discussion

Diabetes had reached pandemic dimensions, which is becoming relevant both in developed and developing countries and affecting over 400 million people worldwide [58]. T2DM represents the most prevalent form because of the huge and heterogeneous number of patients [59]. Diabetes can cause long-term damage, dysfunction and failure of different organs, such as the eyes (blindness/retinopathy), kidneys (renal failure), nerves (diabetes peripheral neuropathy), heart (cardiovascular diseases) and blood vessels (diabetic foot disorders) [2, 4, 60]. Based on above data, prevention and treatment to DM, especially T2DM could be a key strategy to reduce the global impact of DM. Currently, there is growing evidence on the efficacy of the use of genetic susceptibility for DM prevention and management [5].

IL-6 is a key anti- and pro-inflammatory cytokine produced mainly by T-cells and macrophages [11], which plays significant roles in the regulation of the autoimmune disease such as T2DM, because elevated levels of IL-6 can be used to predict the development. A common polymorphism (rs1800795) in the promoter of IL- 6 gene has been widely reported, and been considered as a risk factor for T2DM based on the change of expression of IL-6 [13]. To data, a number of studies have been focused on the relationship between IL-6 rs1800795 polymorphism and DM risk [26, 29, 30, 38]. In addition, some articles about meta-analysis also shown the conclusions above association [21-24], However, lack of powerful and convincing conclusions remain exist. So, it is necessary to re-combine previous published studies to make a comprehensive meta-analysis to solve above association.

To our best knowledge, meta-analysis is a powerful method to carry out inconsistent results based on large number of samples including different ethnicities or countries [24]. The conclusion obtained from meta-analysis is more reliable and persuasive than one single study [24]. To investigate the association between IL-6 rs1800795 and DM, our studies is a timely and comprehensive study including 39099 individuals. Our results indicated that IL-6 rs1800795 acted as a protective factor in T2DM, in other words, individuals carrying C-allele may have decreased association with T2DM, especially for Asians and HB source studies. However, IL-6 rs1800795 was a risk factor in T1DM, there 
had a significantly increased association between this polymorphism and TIDM risk in four genetic models in Mixed population and HB source studies.

Above information indicated IL-6 rs1800795 polymorphism may have different effect in different types of DM, and also exist different influences for different ethnicities, such as Asians and Mixed population. Some potential reasons may be explained: the pathogenic mechanisms about T2DM and T1DM is different, many significant expressed genes are not exactly the same, on the other hand, the same gene may have different effects, even the opposite results, based on current results, IL- 6 gene may have different way between T2DM and T1DM, so rs1800795 polymorphism affecting expression of IL-6 also have different roles between T2DM and T1DM. Different races includes heterogeneity, the same gene also may have different roles in different ethnicities [61, 62]. Third, the heterogeneity about selection strategy also maybe exist, which should affect our results. Furthermore, to evaluate the stable and convince of current study, we applied the Power analysis. Finally, the power in T2DM was 1, however, in T1DM was 0.166, which means the conclusions from T2DM was powerful and persuasive, rather than for T1DM. That suggested more studies about rs1800795 and T1DM risk should be added in the future to obtain a trustworthy conclusion.

Although we made a comprehensive meta-analysis, several limitations also should be considered. First of all, the studies from Mixed population and Africans are limited, which lead to missing or insufficient results, finally may influence the whole conclusion. Second, one signal gene or one polymorphism may not have the power to result in the development of DM, which is a complex process including gene-gene or gene-environment interaction, further studies should pay close attention above content. Third, four databases were included, some valuable studies from other databases or other languages may not be identified, which should have an impact to current conclusions.

\section{Conclusions}

In summary, our present meta-analysis provided evidence that the IL-6 rs1800795 polymorphism was associated with significantly increased T1DM risk in Mixed population, in opposite, decreased 
association were found in T2DM susceptibility in Asians. Consequently, further well-designed large studies, particularly those related to gene-gene and gene-environment interactions, are warranted. Declarations

\section{Acknowledgements}

Not applicable.

\section{Authors' contributions}

ZC and CZ designed and conceived this study. CZ contributed to literature searching. CZ were involved in data extraction. ZC analyzed the data. ZC wrote the manuscript. ZC revised the paper. All authors have approved the final edition of the manuscript.

\section{Availability of data and materials}

All the data generated in the present research is contained in this manuscript.

\section{Ethics approval and consent to participate}

Not applicable.

\section{Consent for publication}

Not applicable.

\section{Competing interests}

The authors declare that they have no competing interests.

References

1. Edgerton DS, Kraft G, Smith M, Farmer B, Williams PE, Coate KC, Printz RL, O'Brien RM, Cherrington AD: Insulin's direct hepatic effect explains the inhibition of glucose production caused by insulin secretion. JCI insight 2017, 2(6):e91863.

2. Association. AD: Diagnosis and classification of diabetes mellitus. Diabetes care 
2010, 33 Suppl 1:S62-69.

3. Diamant $A L$, Babey $\mathrm{SH}$, Hastert $T A$, Brown $E R$ : Diabetes: the growing epidemic. Policy brief (UCLA Center for Health Policy Research) 2007(Pb2007-9):1-12.

4. Marciano L, Camerini AL, Schulz PJ: The Role of Health Literacy in Diabetes Knowledge, Self-Care, and Glycemic Control: a Meta-analysis. Journal of general internal medicine 2019, 34(6):1007-1017.

5. Khan RMM, Chua ZJY, Tan JC, Yang Y, Liao Z, Zhao Y: From Pre-Diabetes to Diabetes: Diagnosis, Treatments and Translational Research. Medicina (Kaunas, Lithuania) 2019, 55(9).

6. Gaulton KJ: Mechanisms of Type 2 Diabetes Risk Loci. Current diabetes reports 2017, 17(9):72.

7. Papazafiropoulou AK, Papanas N, Melidonis A, Maltezos E: Family History of Type 2 Diabetes: Does Having a Diabetic Parent Increase the Risk? Current diabetes reviews 2017, 13(1):19-25.

8. Pickup JC, Mattock MB, Chusney GD, Burt D: NIDDM as a disease of the innate immune system: association of acute-phase reactants and interleukin-6 with metabolic syndrome X. Diabetologia 1997, 40(11):1286-1292.

9. Campbell IL, Kay TW, Oxbrow L, Harrison LC: Essential role for interferon-gamma and interleukin-6 in autoimmune insulin-dependent diabetes in NOD/Wehi mice. The Journal of clinical investigation 1991, 87(2):739-742.

10. Foulis AK, Farquharson MA, Meager A: Immunoreactive alpha-interferon in insulin-secreting beta cells in type 1 diabetes mellitus. Lancet (London, England) 1987, 2(8573):1423-1427.

11. Bowcock AM, Kidd JR, Lathrop GM, Daneshvar L, May LT, Ray A, Sehgal PB, Kidd KK, Cavalli-Sforza LL: The human "interferon-beta 2/hepatocyte stimulating 
factor/interleukin-6" gene: DNA polymorphism studies and localization to chromosome 7p21. Genomics 1988, 3(1):8-16.

12. Vozarova B, Fernandez-Real JM, Knowler WC, Gallart L, Hanson RL, Gruber JD, Ricart W, Vendrell J, Richart C, Tataranni PA et al: The interleukin-6 (-174) G/C promoter polymorphism is associated with type-2 diabetes mellitus in Native Americans and Caucasians. Human genetics 2003, 112(4):409-413.

13. Fishman D, Faulds G, Jeffery R, Mohamed-Ali V, Yudkin JS, Humphries S, Woo P: The effect of novel polymorphisms in the interleukin-6 (IL-6) gene on IL-6 transcription and plasma IL-6 levels, and an association with systemic-onset juvenile chronic arthritis. The Journal of clinical investigation 1998, 102(7):13691376.

14. Larcombe LA, Orr PH, Lodge AM, Brown JS, Dembinski IJ, Milligan LC, Larcombe EA, Martin BD, Nickerson PW: Functional gene polymorphisms in canadian aboriginal populations with high rates of tuberculosis. The Journal of infectious diseases 2008, 198(8):1175-1179.

15. Nadeem A, Mumtaz S, Naveed AK, Mansoor Q, Aslam M, Siddiqui A, Ismail M: Association of IL-6 C-174G (rs 1800795) single nucleotide polymorphism with type 2 diabetes mellitus in Pakistani population. JPMA The Journal of the Pakistan Medical Association 2017, 67(3):428-433.

16. Saxena M, Agrawal CG, Srivastava N, Banerjee M: Interleukin-6 (IL-6)-597 A/G (rs1800797) \&-174 G/C (rs1800795) gene polymorphisms in type 2 diabetes. The Indian journal of medical research 2014, 140(1):60-68.

17. Dhamodharan U, Viswanathan V, Krishnamoorthy E, Rajaram R, Aravindhan V: Genetic association of IL-6, TNF-alpha and SDF-1 polymorphisms with serum cytokine levels in diabetic foot ulcer. Gene 2015, 565(1):62-67. 
18. Fathy SA, Mohamed MR, Ali MAM, El-Helaly AE, Alattar AT: Influence of IL-6, IL-10, IFN-gamma and TNF-alpha genetic variants on susceptibility to diabetic kidney disease in type 2 diabetes mellitus patients. Biomarkers 2019, 24(1):4355.

19. Cooper JD, Smyth DJ, Bailey R, Payne F, Downes K, Godfrey LM, Masters J, Zeitels LR, Vella A, Walker NM et al: The candidate genes TAF5L, TCF7, PDCD1, IL6 and ICAMI cannot be excluded from having effects in type 1 diabetes. $B M C$ medical genetics 2007, 8:71.

20. Tsiavou A, Hatziagelaki E, Chaidaroglou A, Manginas A, Koniavitou K, Degiannis D, Raptis SA: TNF-alpha, TGF-beta1, IL-10, IL-6, gene polymorphisms in latent autoimmune diabetes of adults (LADA) and type 2 diabetes mellitus. Journal of clinical immunology 2004, 24(6):591-599.

21. Xu WD, Zhou M, Peng H, Pan HF, Ye DQ: Lack of association of IL-6 polymorphism with rheumatoid arthritis/type 1 diabetes: a meta-analysis. Joint, bone, spine : revue du rhumatisme $2013, \mathbf{8 0}(5): 477-481$.

22. Yin YW, Sun QQ, Zhang BB, Hu AM, Wang Q, Liu HL, Hou ZZ, Zeng YH, Xu RJ, Shi LB: The lack of association between interleukin-6 gene -174 G/C polymorphism and the risk of type 1 diabetes mellitus: a meta-analysis of 18,152 subjects. Gene 2013, 515(2):461-465.

23. Huth C, Heid IM, Vollmert C, Gieger C, Grallert H, Wolford JK, Langer B, Thorand B, Klopp N, Hamid YH et al: IL6 gene promoter polymorphisms and type 2 diabetes: joint analysis of individual participants' data from 21 studies. Diabetes 2006, 55(10):2915-2921.

24. Xia J, Sun RL: Association between interleukin-6 rs1800795 polymorphism and the decreased risk of type 2 diabetes mellitus: an updated meta-analysis. Int 
J Clin Exp Med 2019, 12(1):86-97.

25. Campos LP, Graciolo V, Sousa MM, Martins BR, Souza SW, Alberton D, Picheth G, Rego FGM: Polymorphisms rs1800795 of interleukin-6 and rs2228145 of interleukin-6 receptor genes in Euro- Brazilians with adult-onset type 1 diabetes mellitus. Genet Mol Res 2019, 18(3):gmr18260.

26. Helaly MA, Hatata EZ, Elmagd MA, Ibrahem EF, Alsajd A, El-Aal IA, Settin A: Association of IL-10 and IL-6 Gene Polymorphisms with Type 2 Diabetes Mellitus among Egyptian Patients. Eur J Gen Med 2013, 10(3):158-162.

27. Chen $X Q, X U Y C$ : Interleukin-6 gene polymorphism and its expression related to the susceptivity of Type two Diabetes. Master's Degree Thesis 2002.

28. Kong JH, Yu M: Study of association of interleukin-6 gene polymorphisms with Type 2 Diabetes Mellitus. Master's Degree Thesis 2010.

29. Bouhaha R, Baroudi T, Ennafaa H, Vaillant E, Abid H, Sassi R, Vatin V, Froguel P, Gaaied AB, Meyre D et al: Study of TNFalpha $-\mathbf{3 0 8 G / A}$ and IL6 -174G/C polymorphisms in type 2 diabetes and obesity risk in the Tunisian population. Clinical biochemistry 2010, 43(6):549-552.

30. Buraczynska M, Zukowski P, Drop B, Baranowicz-Gaszczyk I, Ksiazek A: Effect of G(-174)C polymorphism in interleukin-6 gene on cardiovascular disease in type 2 diabetes patients. Cytokine 2016, 79:7-11.

31. Danielsson P, Truedsson L, Eriksson KF, Norgren L: Inflammatory markers and IL-6 polymorphism in peripheral arterial disease with and without diabetes mellitus. Vascular medicine (London, England) 2005, 10(3):191-198.

32. Erdogan M, Kulaksizoglu M, Solmaz S, Berdeli A: The relationship of Interleukin-6 -174 G>C gene polymorphism in type 2 diabetic patients with and without diabetic foot ulcers in Turkish population. Foot (Edinburgh, Scotland) 2017, 
30:27-31.

33. Eze IC, Imboden M, Kumar A, Adam M, von Eckardstein A, Stolz D, Gerbase MW, Kunzli N, Turk A, Schindler Cet al: A common functional variant on the proinflammatory Interleukin-6 gene may modify the association between longterm PM10 exposure and diabetes. Environmental health : a global access science source $2016,15: 39$.

34. Ghavimi R, Sharifi M, Mohaghegh MA, Mohammadian H, Khadempar S, Rezaei H: Lack of association between rs1800795 (-174 G/C) polymorphism in the promoter region of interleukin-6 gene and susceptibility to type 2 diabetes in Isfahan population. Advanced biomedical research 2016, 5:18.

35. Hamid YH, Rose CS, Urhammer SA, Glumer C, Nolsoe R, Kristiansen OP, MandrupPoulsen T, Borch-Johnsen K, Jorgensen T, Hansen T et al: Variations of the interleukin-6 promoter are associated with features of the metabolic syndrome in Caucasian Danes. Diabetologia 2005, 48(2):251-260.

36. Jahromi MM, Millward BA, Demaine AG: A polymorphism in the promoter region of the gene for interleukin-6 is associated with susceptibility to type 1 diabetes mellitus. Journal of interferon \& cytokine research : the official journal of the International Society for Interferon and Cytokine Research 2000, 20(10):885-888.

37. Javor J, Ferencik S, Bucova M, Stuchlikova M, Martinka E, Barak L, Strbova L, GrosseWilde H, Buc M: Polymorphisms in the genes encoding TGF-beta1, TNF-alpha, and IL-6 show association with type 1 diabetes mellitus in the Slovak population. Archivum immunologiae et therapiae experimentalis 2010, 58(5):385393.

38. Karadeniz M, Erdogan M, Berdeli A, Yilmaz C: Association of interleukin-6 -174 G $>$ C promoter polymorphism with increased risk of type 2 diabetes mellitus 
patients with diabetic nephropathy in Turkey. Genetic testing and molecular biomarkers 2014, 18(1):62-65.

39. Kavitha L, Vijayshree Priyadharshini J, Sivapathasundharam B: Association among interleukin-6 gene polymorphisms, type 2 diabetes mellitus, and chronic periodontitis: a pilot study. Journal of investigative and clinical dentistry 2017, 8(3).

40. Lara-Gomez RE, Moreno-Cortes ML, Muniz-Salazar R, Zenteno-Cuevas R: Association of polymorphisms at -174 in IL-6, and -308 and -238 in TNF-alpha, in the development of tuberculosis and type 2 diabetes mellitus in the Mexican population. Gene 2019, 702:1-7.

41. Mohlig M, Boeing H, Spranger J, Osterhoff M, Kroke A, Fisher E, Bergmann MM, Ristow M, Hoffmann K, Pfeiffer AF: Body mass index and C-174G interleukin-6 promoter polymorphism interact in predicting type 2 diabetes. The Journal of clinical endocrinology and metabolism 2004, 89(4):1885-1890.

42. Mukhopadhyaya PN, Acharya A, Chavan Y, Purohit SS, Mutha A: Metagenomic study of single-nucleotide polymorphism within candidate genes associated with type 2 diabetes in an Indian population. Genetics and molecular research : GMR $2010,9(4): 2060-2068$.

43. Mysliwiec M, Mysliwska J, Zorena K, Balcerska A, Malinowska E, Wisniewski P: Interleukin $6-174(G>C)$ gene polymorphism is related to celiac disease and autoimmune thyroiditis coincidence in diabetes type 1 children. Diabetes research and clinical practice 2008, 82(1):108-112.

44. Mysliwska J, Zorena K, Mysliwiec M, Malinowska E, Raczynska K, Balcerska A: The -174GG interleukin-6 genotype is protective from retinopathy and nephropathy in juvenile onset type 1 diabetes mellitus. Pediatric research 
$2009,66(3): 341-345$.

45. Neelofar K, Ahmad J, Ahmad A, Alam K: Study of IL4-590C/T and IL6-174G/C Gene Polymorphisms in Type 2 Diabetic Patients With Chronic Kidney Disease in North Indian Population. Journal of cellular biochemistry 2017, 118(7):1803-1809.

46. Perez-Bravo F, Soto MF, Lopez AP, Eyzaguirre CF, Codner E: [-174 G/C polymorphism of interleukin 6 gene in women with type 1 diabetes]. Revista medica de Chile 2011, 139(2):158-164.

47. Plataki MN, Zervou MI, Samonis G, Daraki V, Goulielmos GN, Kofteridis DP:

Association of the Interleukin-6 rs1800795 Polymorphism with Type 2 Diabetes Mellitus in the Population of the Island of Crete, Greece. Genetic testing and molecular biomarkers 2018, 22(7):448-452.

48. Settin A, Ismail A, El-Magd MA, El-Baz R, Kazamel A: Gene polymorphisms of TNFalpha-308 (G/A), IL-10(-1082) (G/A), IL-6(-174) (G/C) and IL-1Ra (VNTR) in Egyptian cases with type 1 diabetes mellitus. Autoimmunity 2009, 42(1):50-55.

49. Siekiera U, Jarosz-Chobot P, Janusz ], Koehler B: [Polymorphism of TNF-alpha (308 A/G), IL-10 (1082 A/G, 819 C/T 592 A/C), IL-6 (174 G/C), and IFN-gamma (874 A/T); genetically conditioned cytokine synthesis level in children with diabetes type 1]. Endokrynologia, diabetologia i choroby przemiany materii wieku rozwojowego : organ Polskiego Towarzystwa Endokrynologow Dzieciecych 2002, 8(1):29-34.

50. Ururahy MA, de Souza KS, Oliveira YM, Loureiro MB, da Silva HP, Freire-Neto FP, Bezerra JF, Luchessi AD, Doi SQ, Hirata RD et al: Association of polymorphisms in IL6 gene promoter region with type 1 diabetes and increased albumin-tocreatinine ratio. Diabetes/metabolism research and reviews 2015, 31(5):500-506.

51. Xiao LM, Yan YX, Xie CJ, Fan WH, Xuan DY, Wang CX, Chen L, Sun SY, Xie BY, Zhang 
JC: Association among interleukin-6 gene polymorphism, diabetes and periodontitis in a Chinese population. Oral diseases 2009, 15(8):547-553.

52. Zhang X, Ma L, Peng F, Wu Y, Chen Y, Yu L, Lei Z, Zhang C: The endothelial dysfunction in patients with type 2 diabetes mellitus is associated with IL-6 gene promoter polymorphism in Chinese population. Endocrine 2011 , 40(1): 124-129.

53. Higgins JP, Thompson SG: Quantifying heterogeneity in a meta-analysis. Statistics in medicine 2002, 21(11):1539-1558.

54. DerSimonian R, Laird N: Meta-analysis in clinical trials. Controlled clinical trials 1986, 7(3):177-188.

55. Mantel N, Haenszel W: Statistical aspects of the analysis of data from retrospective studies of disease. Journal of the National Cancer Institute 1959, $22(4): 719-748$.

56. Hayashino Y, Noguchi Y, Fukui T: Systematic evaluation and comparison of statistical tests for publication bias. Journal of epidemiology 2005, 15(6):235243.

57. Napolioni $V$ : The relevance of checking population allele frequencies and Hardy-Weinberg Equilibrium in genetic association studies: the case of SLC6A4 5-HTTLPR polymorphism in a Chinese Han Irritable Bowel Syndrome association study. Immunology letters 2014, 162(1 Pt A):276-278.

58. (IDF). IDF: IDF Diabetes Altas, 8th ed. International Diabetes Federation 2017, Brussels, Belgium,:ISBN 9782930229874.

59. (WHO). WHO: Global Report on Diabetes. World Health Organization 2016 , Geneva, Switzerland,.

60. Pantalone KM, Hobbs TM, Wells BJ, Kong SX, Kattan MW, Bouchard J, Yu C, Sakurada 
B, Milinovich A, Weng Wet al: Clinical characteristics, complications, comorbidities and treatment patterns among patients with type 2 diabetes mellitus in a large integrated health system. BMJ open diabetes research \& care 2015, 3(1):e000093.

61. Mi YY, Yu QQ, Xu B, Zhang LF, Min ZC, Hua LX, Feng NH, Yao Y: Interferon gamma +874 T/A polymorphism contributes to cancer susceptibility: a meta-analysis based on 17 case-control studies. Molecular biology reports 2011, 38(7):44614467.

62. Mi YY, Yu QQ, Yu ML, Xu B, Zhang LF, Cheng W, Zhang W, Hua LX, Feng NH: Review and pooled analysis of studies on $-607(\mathrm{C} / \mathrm{A})$ and $-137(\mathrm{G} / \mathrm{C})$ polymorphisms in IL-18 and cancer risk. Medical oncology (Northwood, London, England) 2011 , 28(4):1107-1115.

Tables

Table 1 Characteristics of studies of IL-6 rs1800795 polymorphism and T2DM and T1DM risk included in our meta-analysis

\begin{tabular}{lrllrrrr}
\hline Author & Year & Country & Ethnicity & Type & Case & Control & SOC \\
& & & & & & \\
\hline Mukhopadhyaya & 2010 & India & Asian & T2DM & 40 & 40 & PB \\
Hamid & 2005 & Denmark & Caucasian & T2DM & 1389 & 4401 & PB \\
Plataki & 2018 & Greece & Caucasian & T2DM & 144 & 180 & HB \\
Vozarova & 2003 & Spain & Caucasian & T2DM & 211 & 118 & PB \\
Buraczynska & 2016 & Poland & Caucasian & T2DM & 1090 & 612 & PB \\
Chen & 2002 & China & Asian & T2DM & 196 & 130 & HB \\
Tsiavou & 2004 & Greece & Caucasian & T2DM & 31 & 39 & HB \\
Eze & 2016 & Switzerland & Caucasian & T2DM & 286 & 5560 & HB \\
Bouhaha & 2010 & Tunisia & African & T2DM & 169 & 281 & PB \\
Ghavimi & 2016 & Iran & Asian & T2DM & 120 & 120 & HB \\
Fathy & 2018 & Kuwait & Asian & T2DM & 50 & 42 & HB \\
Lara-Gómez & 2019 & Mexico & Mixed & T2DM & 31 & 30 & HB \\
Dhamodharan & 2015 & India & Asian & T2DM & 139 & 106 & HB \\
Danielsson & 2005 & Sweden & Caucasian & T2DM & 20 & 20 & HB
\end{tabular}




\begin{tabular}{|c|c|c|c|c|c|c|c|}
\hline Vozarova & 2003 & Spain & Caucasian & T2DM & 143 & 145 & PB \\
\hline Neelofar & 2017 & India & Asian & T2DM & 50 & 50 & $\mathrm{HB}$ \\
\hline Kavitha & 2016 & India & Asian & T2DM & 30 & 30 & $\mathrm{HB}$ \\
\hline Kong & 2010 & China & Asian & T2DM & 107 & 121 & $\mathrm{HB}$ \\
\hline Zhang & 2011 & China & Asian & T2DM & 512 & 483 & $\mathrm{HB}$ \\
\hline Saxena & 2014 & India & Asian & T2DM & 213 & 145 & $\mathrm{HB}$ \\
\hline Xiao & 2009 & China & Asian & T2DM & 85 & 132 & $\mathrm{HB}$ \\
\hline Nadeem & 2017 & Pakistan & Asian & T2DM & 539 & 250 & $\mathrm{HB}$ \\
\hline Mohlig & 2004 & Germany & Caucasian & T2DM & 188 & 376 & $\mathrm{HB}$ \\
\hline Karadeniz & 2014 & Turkey & Caucasian & T2DM & 86 & 340 & $\mathrm{HB}$ \\
\hline Erdogan & 2017 & Turkey & Caucasian & T2DM & 35 & 119 & $\mathrm{HB}$ \\
\hline Helaly & 2013 & Egypt & African & T2DM & 69 & 98 & PB \\
\hline Mysliwiec & 2008 & Poland & Caucasian & T1DM & 200 & 172 & $\mathrm{HB}$ \\
\hline Siekiera & 2002 & Poland & Caucasian & T1DM & 36 & 36 & $\mathrm{HB}$ \\
\hline Ururahy & 2015 & Brazil & Mixed & T1DM & 120 & 152 & $\mathrm{HB}$ \\
\hline Settin & 2009 & Egypt & African & T1DM & 50 & 98 & PB \\
\hline Javor & 2010 & Slovakia & Caucasian & T1DM & 151 & 140 & PB \\
\hline Campos & 2019 & Brasil & Mixed & T1DM & 141 & 150 & $\mathrm{HB}$ \\
\hline Cooper & 2007 & USA & Caucasian & T1DM & 8852 & 7785 & PB \\
\hline Jahromi & 2000 & England & Caucasian & T1DM & 257 & 120 & PB \\
\hline Tsiavou & 2004 & Greece & Caucasian & T1DM & 31 & 39 & PB \\
\hline Mysliwska & 2009 & Poland & Caucasian & T1DM & 210 & 170 & PB \\
\hline Perez-Bravo & 2011 & Chile & Mixed & T1DM & 145 & 103 & PB \\
\hline
\end{tabular}

HB: hospital-based; PB: population-based; SOC; source of control; PCR-RFLP: polymerase chain reaction followed by restriction fragment length polymorphism; PCR-SSPpolymerase chain reaction followed with sequence specific primers; MALDI-TOF: a chip-based matrix-assisted laserdesorption/ionization time-of-flight; HWE: Hardy-Weinberg equilibrium of control group.

Table 2 Stratified analyses of IL-6 rs1800795 polymorphism and T2DM risk. 


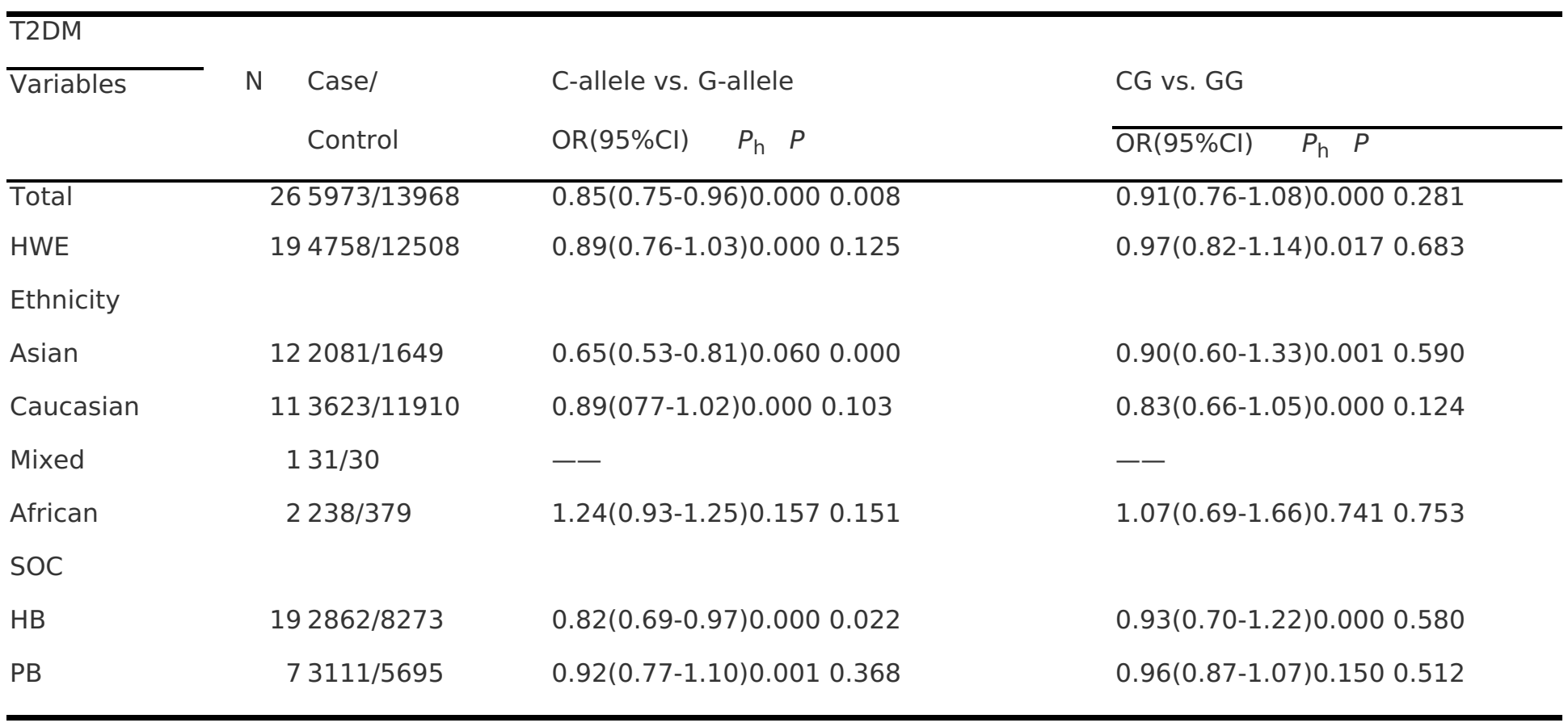

$\boldsymbol{P}_{\mathrm{h}}$ : value of $Q$-test for heterogeneity test; $P$ : Z-test for the statistical significance of the OR, SOC:

source of control; HB: hospital-based; PB: population-based

Table 3 Stratified analyses of IL-6 rs1800795 polymorphism and T1DM risk.

\begin{tabular}{|c|c|c|c|c|c|}
\hline \multirow[t]{2}{*}{ Variables } & \multirow[t]{2}{*}{$\mathrm{N}$} & \multirow{2}{*}{$\begin{array}{l}\text { Case/ } \\
\text { Control }\end{array}$} & C-allele vs. G-allele & CG vs. GG & C \\
\hline & & & OR(95\%Cl) $\quad P_{\mathrm{h}} P$ & OR(95\%Cl) $\quad P_{\mathrm{h}} \quad P$ & $\bar{C}$ \\
\hline Total & 11 & $10193 / 8965$ & $1.16(0.94-1.42) 0.0000 .162$ & $1.33(0.99-1.77) 0.0000 .056$ & 1 \\
\hline HWE & 9 & $9933 / 8697$ & $1.09(0.87-1.36) 0.0000 .461$ & $1.19(0.89-1.58) 0.0030 .235$ & 1 \\
\hline \multicolumn{6}{|l|}{ Ethnicity } \\
\hline Caucasian & 7 & $9737 / 8462$ & $1.06(0.81-1.38) 0.0000 .682$ & $1.37(0.90-2.11) 0.0000 .146$ & 1 \\
\hline Mixed & 3 & $406 / 405$ & $1.39(1.10-1.77) 0.4970 .006$ & $1.33(0.99-1.79) 0.8350 .059$ & 1 \\
\hline African & 1 & $50 / 98$ & - & - & - \\
\hline \multicolumn{6}{|l|}{ SOC } \\
\hline HB & 4 & $497 / 510$ & $1.29(1.07-1.56) 0.1220 .009$ & $1.47(1.11-1.94) 0.4280 .008$ & 1 \\
\hline PB & 7 & $9696 / 8455$ & $1.13(0.86-1.48) 0.0000 .367$ & $1.27(0.85-1.90) 0.0000 .248$ & 1 \\
\hline
\end{tabular}

$P_{\mathrm{h}}$ : value of $Q$-test for heterogeneity test; $P$ : $Z$-test for the statistical significance of the OR, SOC:

source of control; HB: hospital-based; PB: population-based 
Table 4 Publication bias tests (Begg's funnel plot and Egger's test for publication bias test) for IL-6 rs1800795 polymorphism and T2DM and T1DM risk

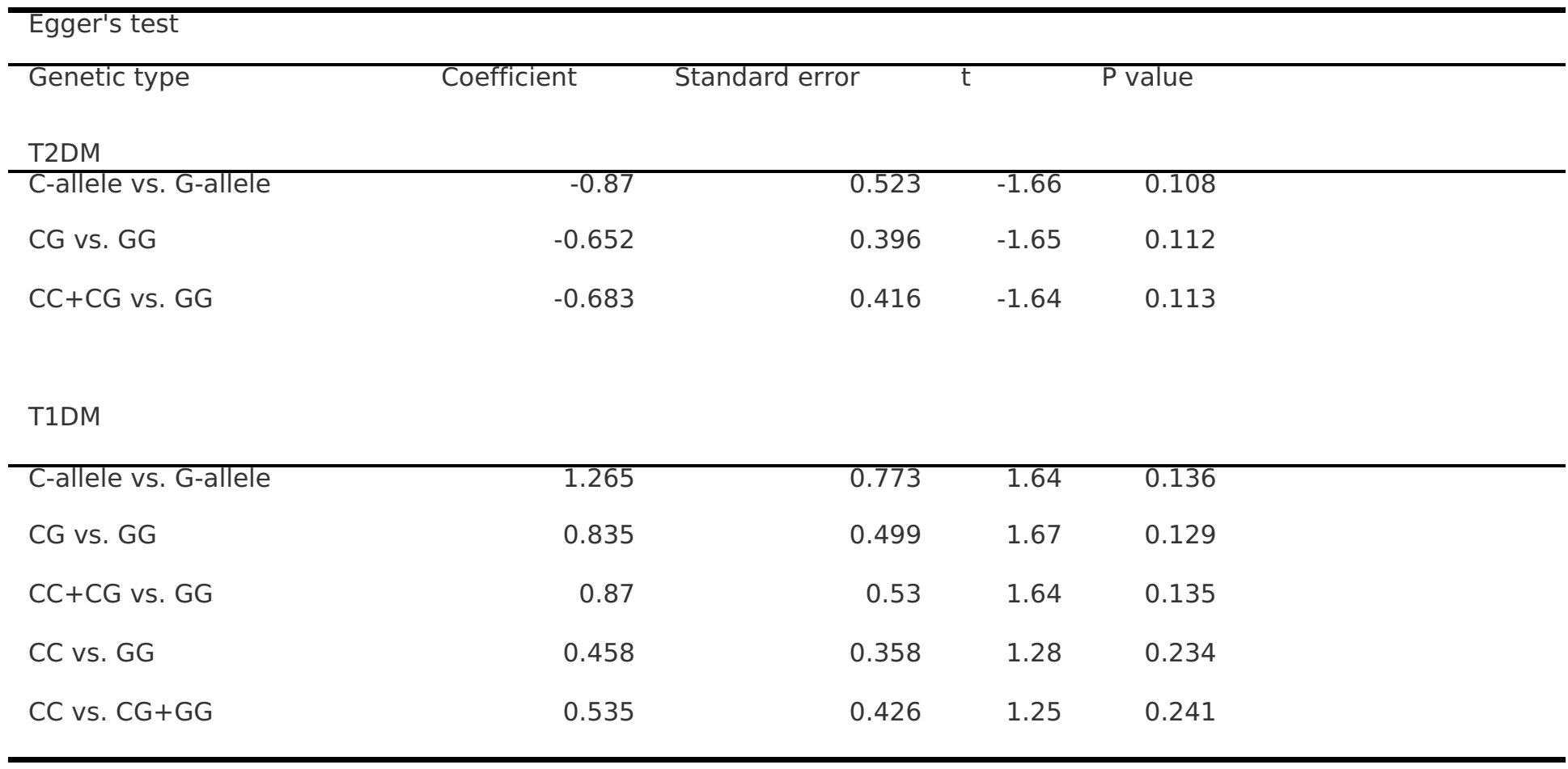

Figures 


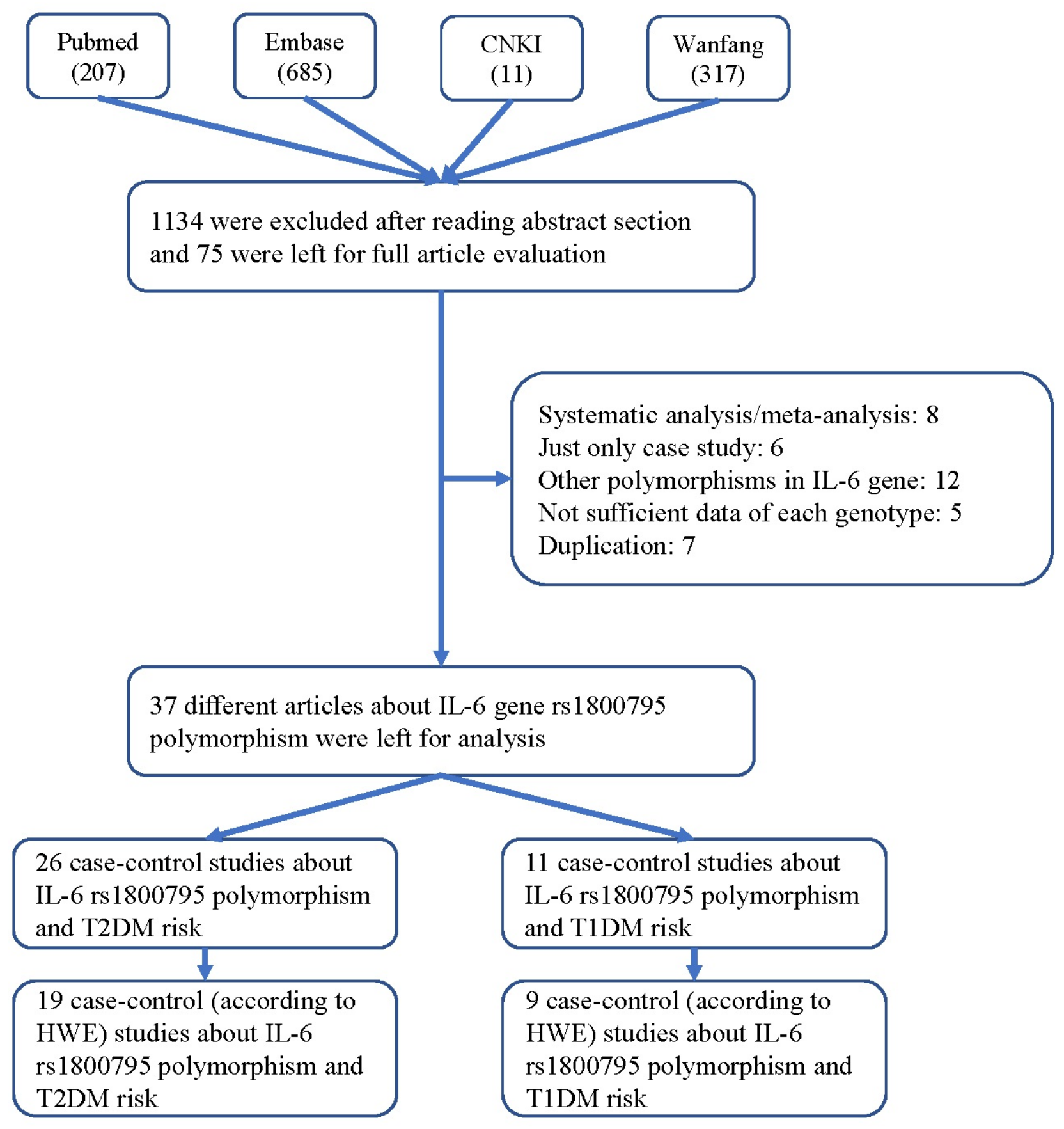

Figure 1

A flowchart illustrating the search strategy used to identify association studies for IL-6 rs1800795 polymorphism and DM risk. 
rs1800795

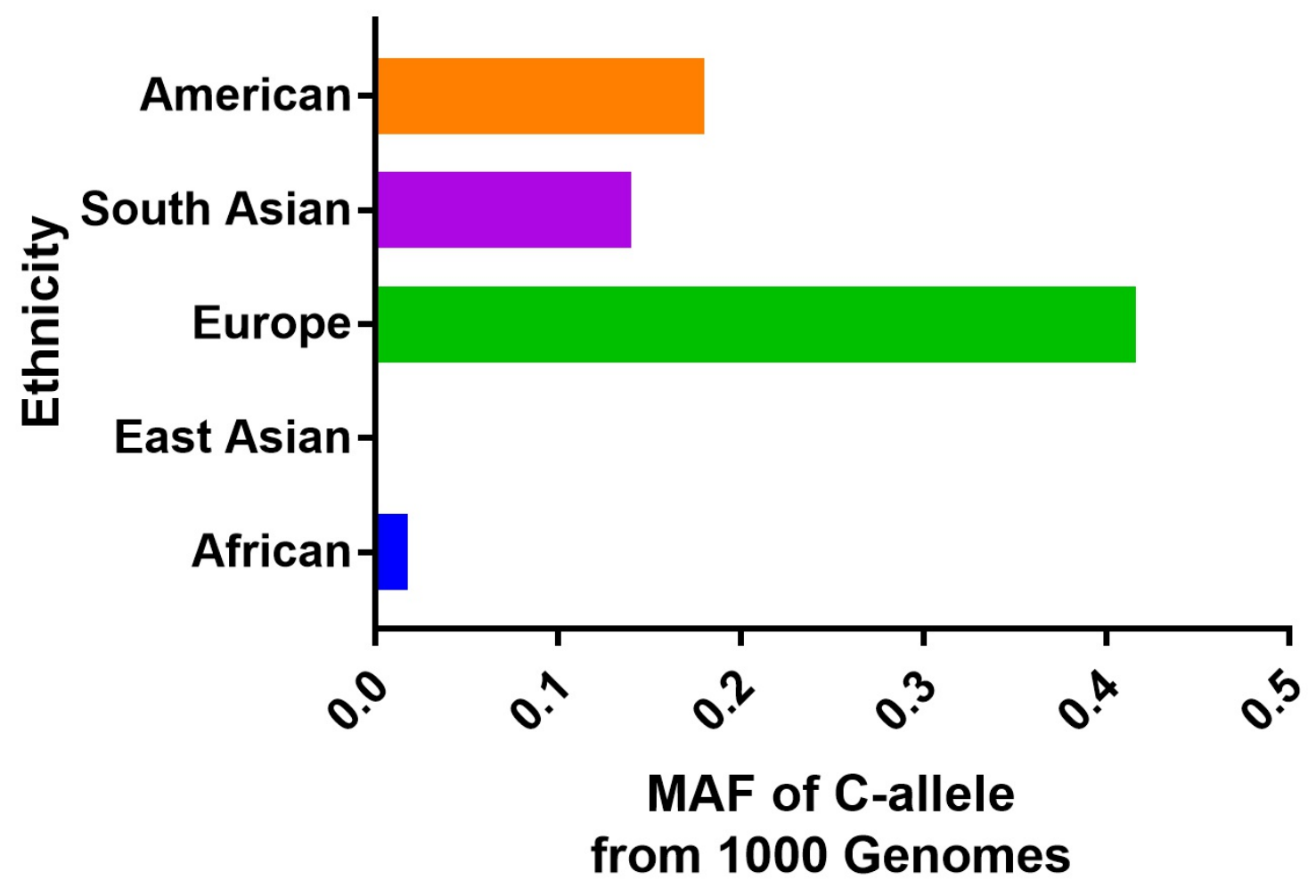

Figure 2

T-allele frequencies for the IL-6 rs1800795 polymorphism among cases/controls stratified by ethnicity. Horizontal line: T-allele frequency; Vertical line: ethnicity type. EAS: East Asian; EUR: European; AFR: African; AMR: American; SAS: South Asian. 
A

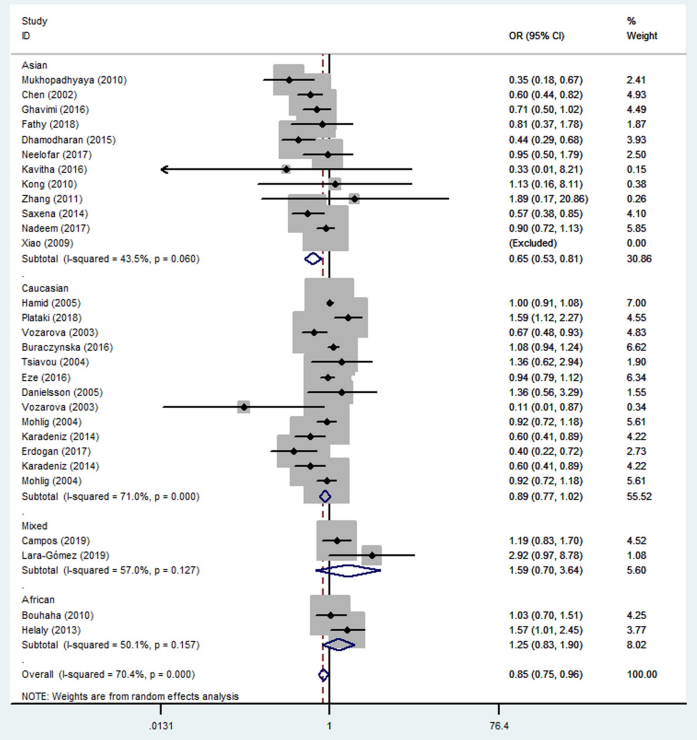

B

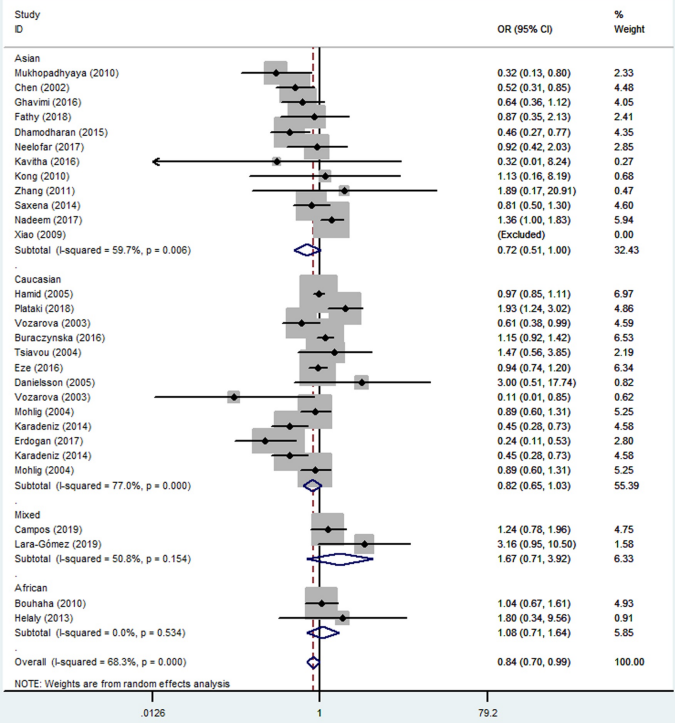

Figure 3

Forest plot of T2DM risk associated with IL-6 rs1800795 polymorphism (A: C-allele vs. G-

allele, B: CC+CG vs. GG) in the subgroup of ethnicity analysis. The squares and horizontal lines correspond to the study-specific OR and $95 \% \mathrm{Cl}$. The area of the squares reflects the weight (inverse of the variance). The diamond represents the summary OR and $95 \% \mathrm{Cl}$. 


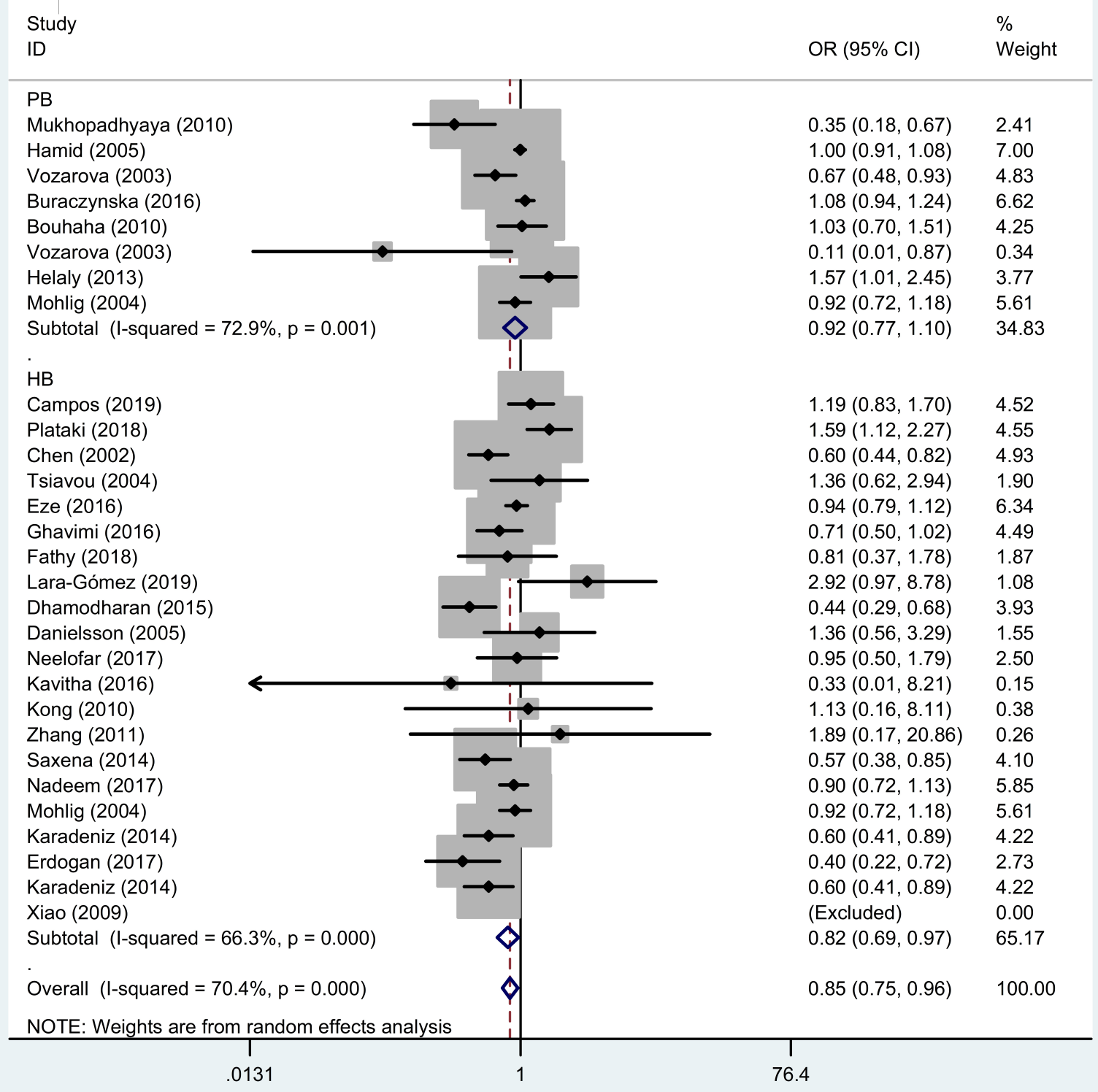

Figure 4

Forest plot of T2DM risk associated with IL-6 rs1800795 polymorphism (C-allele vs. G-allele) in the source of control subgroup. The squares and horizontal lines correspond to the studyspecific OR and $95 \% \mathrm{Cl}$. The area of the squares reflects the weight (inverse of the variance). The diamond represents the summary OR and $95 \% \mathrm{Cl}$. 
A

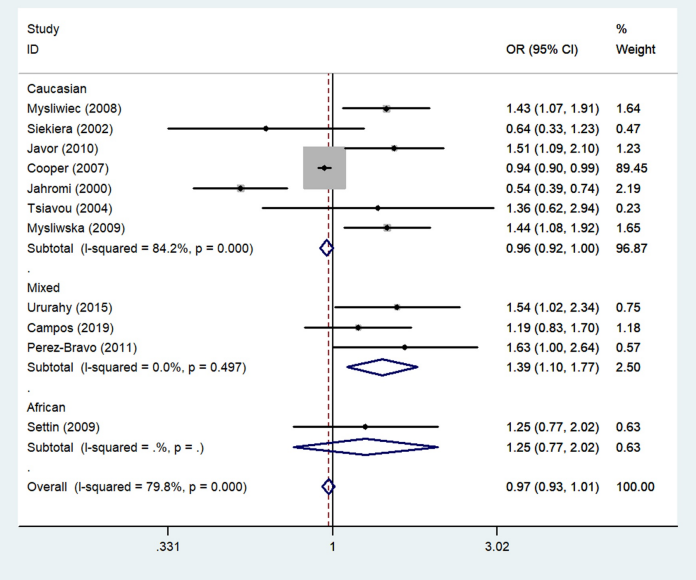

C

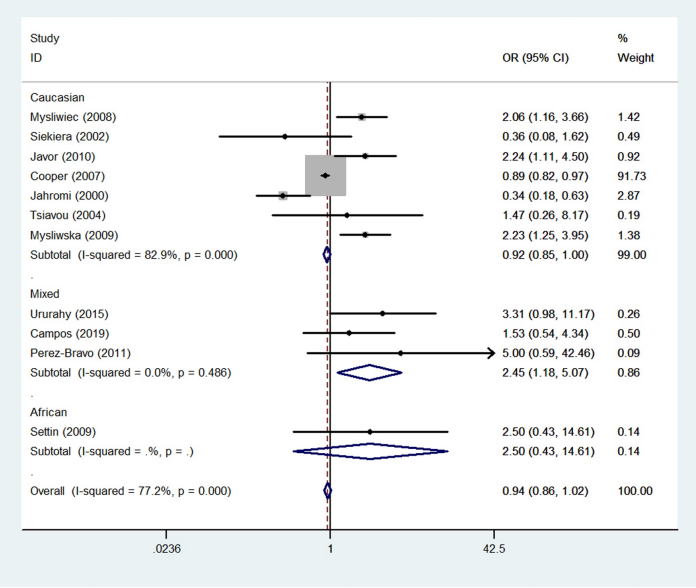

B

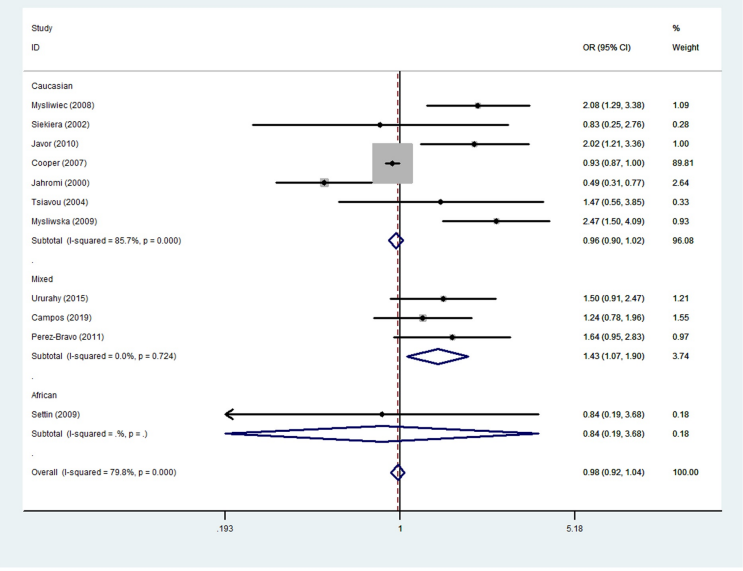

D

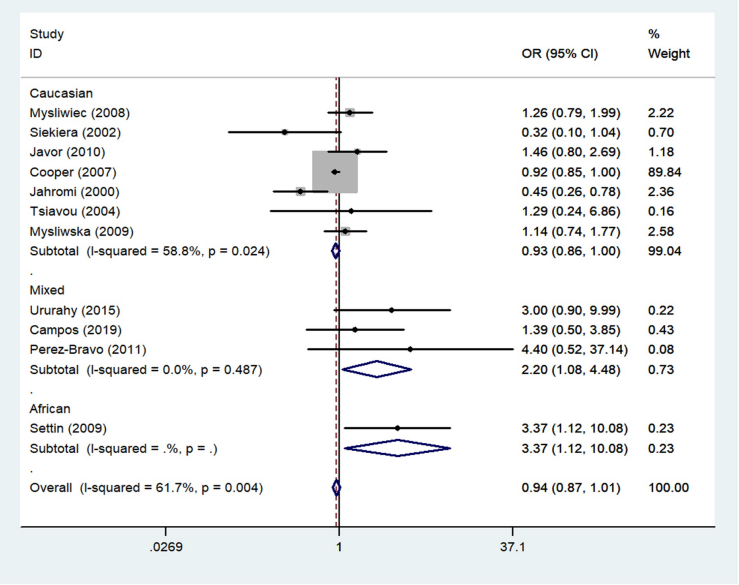

Figure 5

Forest plot of T1DM risk associated with IL-6 rs1800795 polymorphism (A: C-allele vs. G-

allele, B: CC+CG vs. GG, C: CC vs. GG, D: CC vs. CG+GG) in the subgroup of ethnicity analysis. The squares and horizontal lines correspond to the study-specific OR and $95 \% \mathrm{Cl}$.

The area of the squares reflects the weight (inverse of the variance). The diamond represents the summary $\mathrm{OR}$ and $95 \% \mathrm{Cl}$. 
A

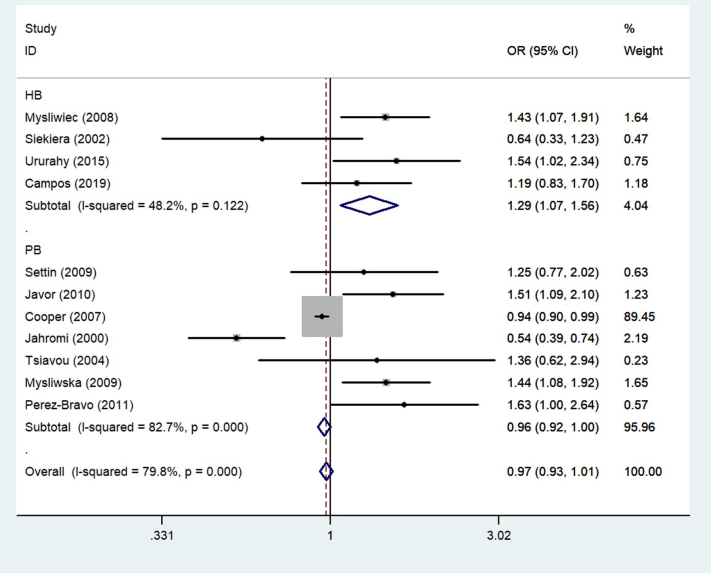

C

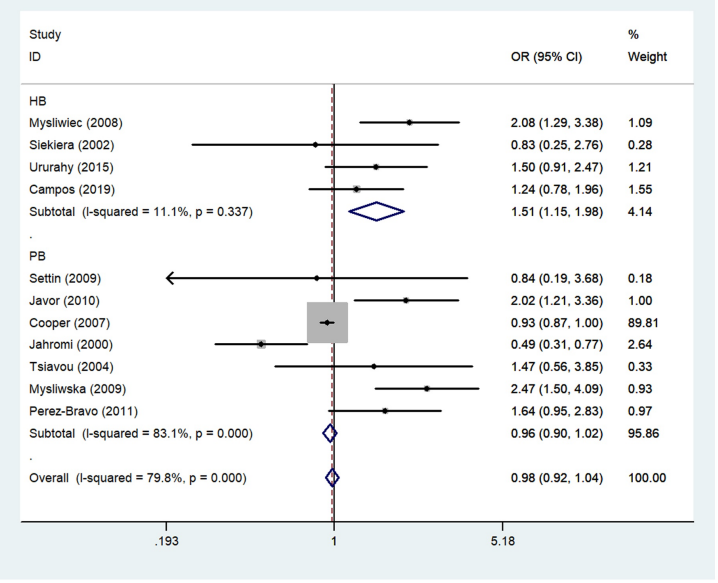

B

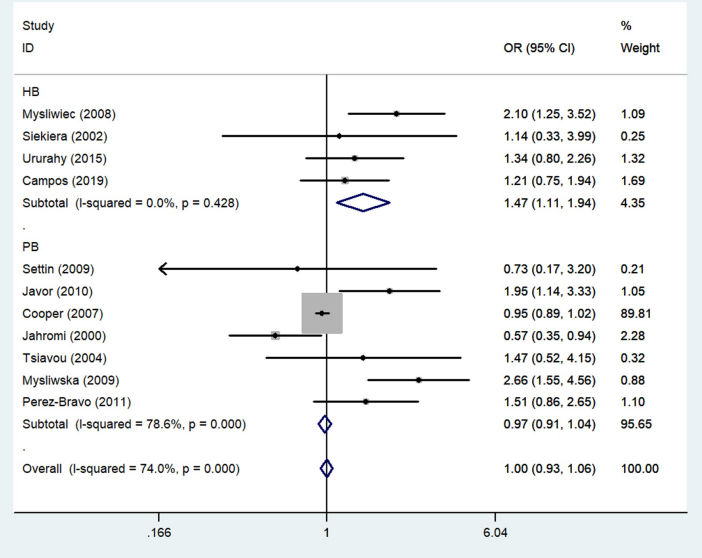

D

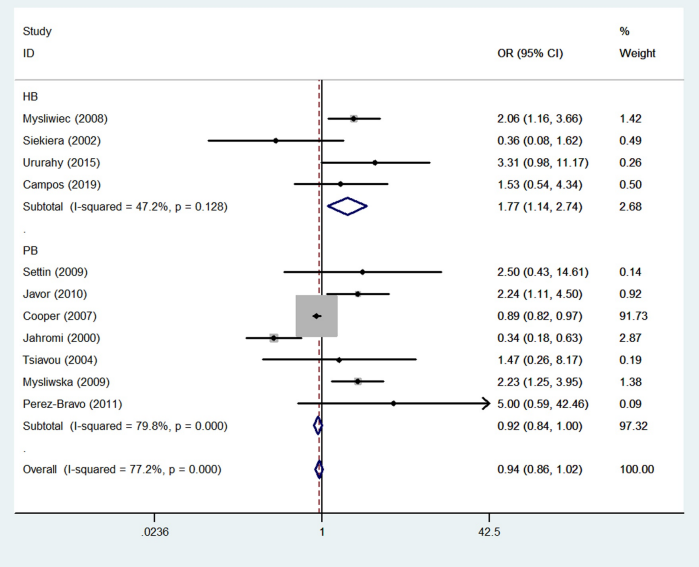

Figure 6

Forest plot of T1DM risk associated with IL-6 rs1800795 polymorphism (A: C-allele vs. Gallele, B: CG vs. GG, C: CC+CG vs. GG, D: CC vs. GG) in the source of control subgroup. The squares and horizontal lines correspond to the study-specific OR and $95 \% \mathrm{Cl}$. The area of the squares reflects the weight (inverse of the variance). The diamond represents the summary OR and $95 \% \mathrm{Cl}$. 

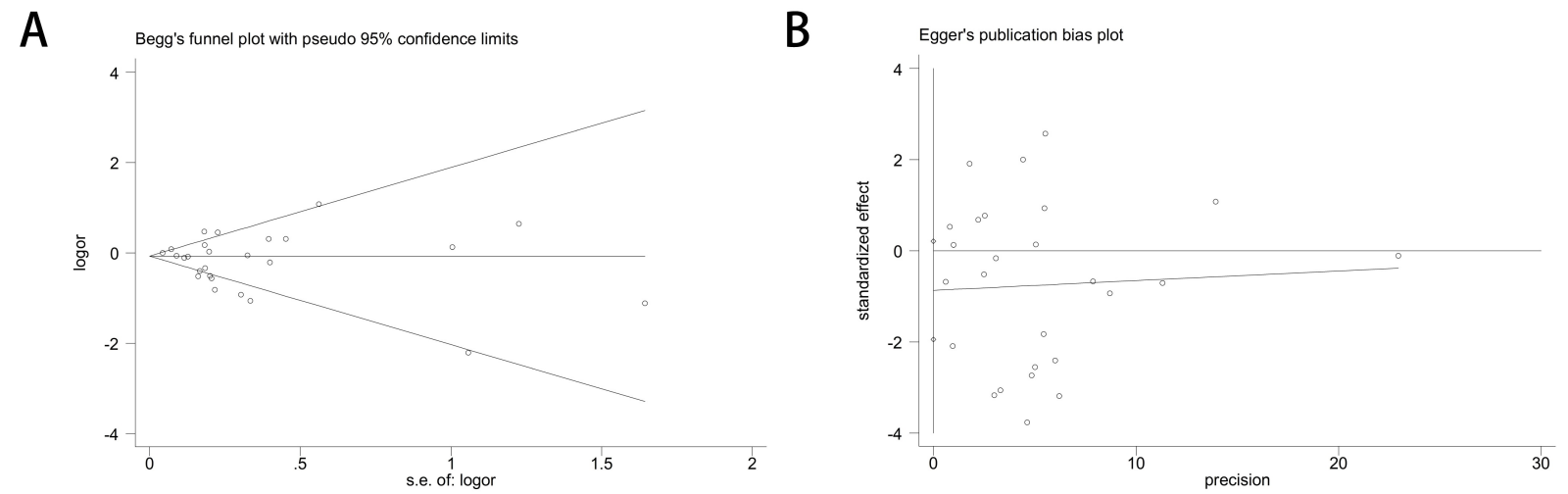

Figure 7

A: Begg's funnel plot for publication bias test (C-allele vs. G-allele). B: Egger's publication bias plot (T-allele vs. G-allele) for T2DM.
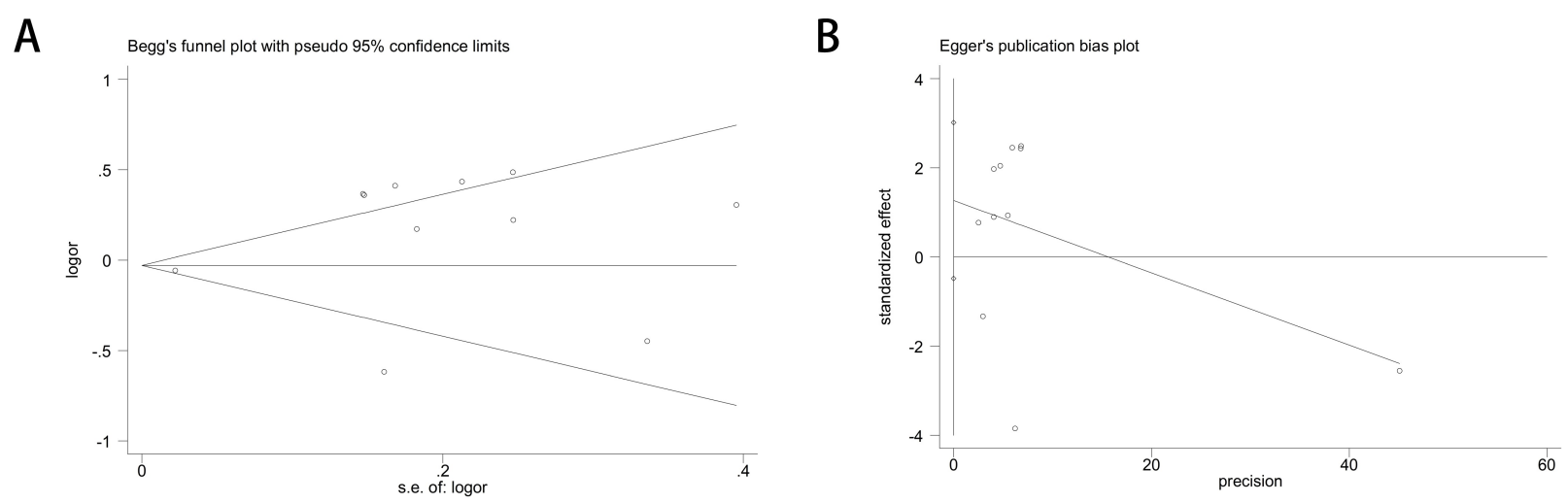

Figure 8

A: Begg's funnel plot for publication bias test (C-allele vs. G-allele). B: Egger's publication bias plot (T-allele vs. G-allele) for T1DM. 


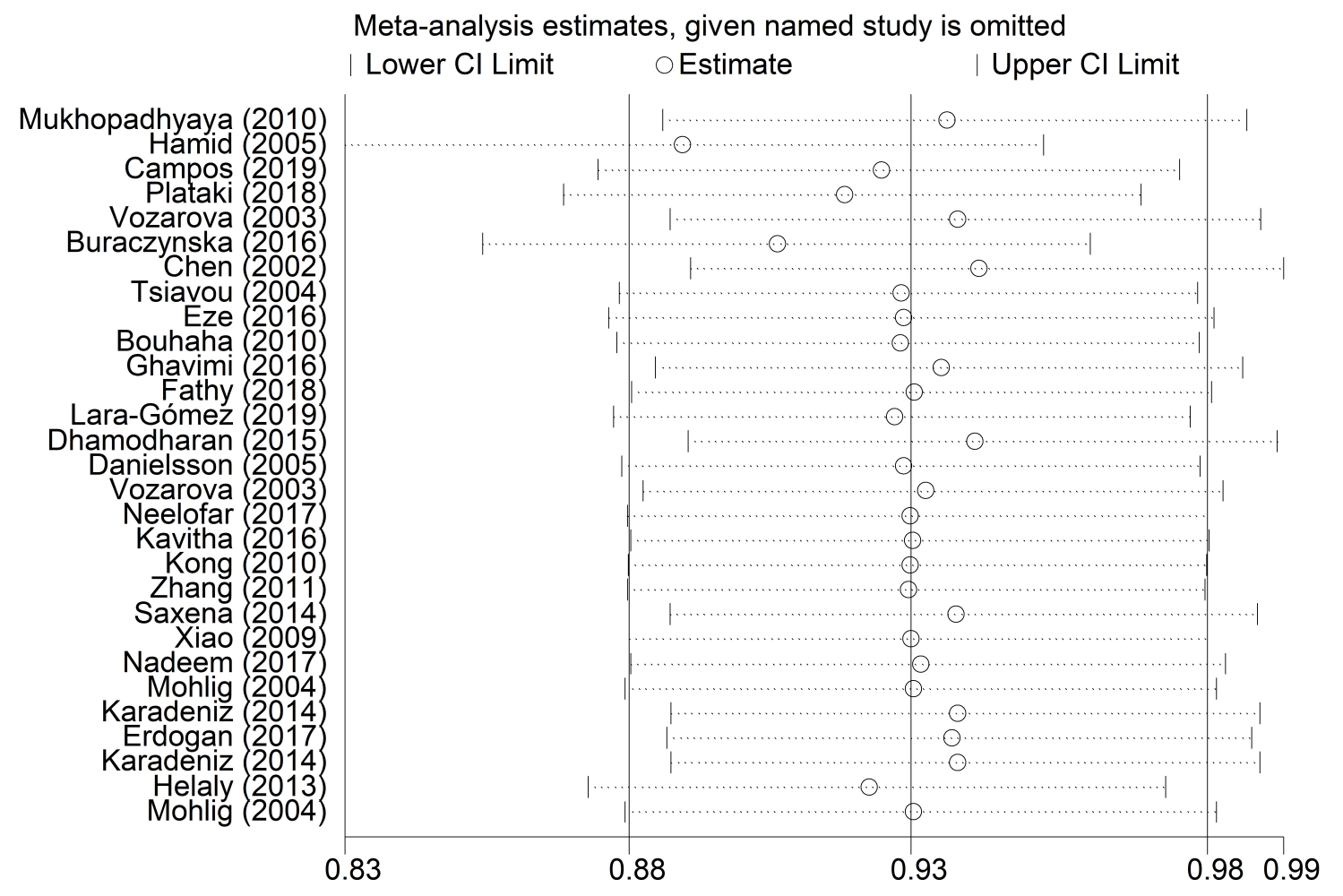

Figure 9

Sensitivity analysis between IL-6 rs1800795 polymorphism and T2DM risk (C-allele vs. Gallele). 


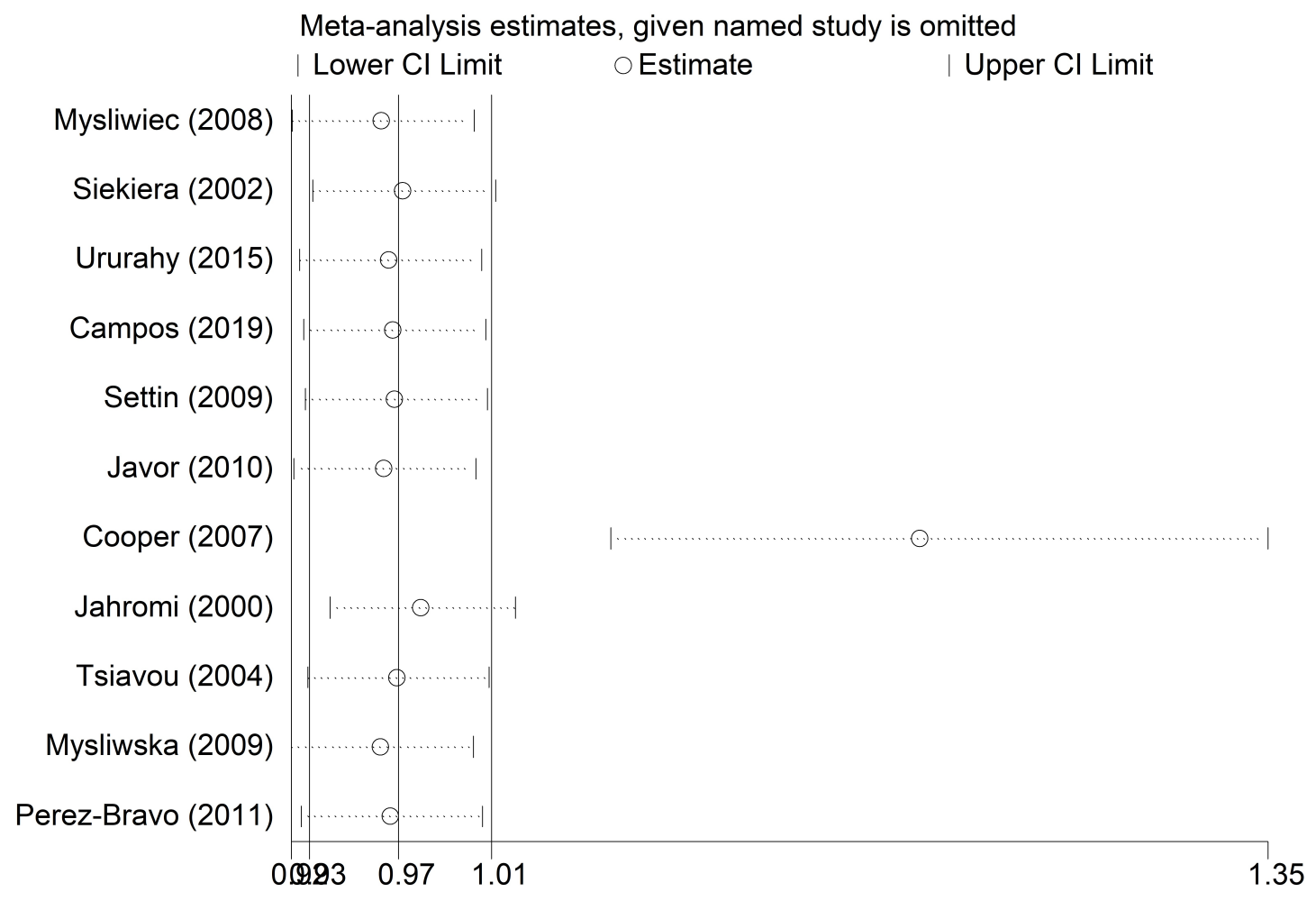

Figure 10

Sensitivity analysis between IL-6 rs1800795 polymorphism and T1DM risk (C-allele vs. Gallele). 